\title{
Plant-Derived Leading Compounds for Chemotherapy of Human Immunodeficiency Virus (HIV) Infection
}

\author{
A. J. Vlietinck*, T. De Bruyne, S. Apers, and L. A. Pieters \\ Department of Pharmaceutical Sciences, University of Antwerp (UA), Antwerp, Belgium
}

Received: October 7, 1997; Accepted: October 18, 1997

\begin{abstract}
Many compounds of plant origin have been identified that inhibit different stages in the replication cycle of human immunodeficiency virus (HIV): 1) virus adsorption: chromone alkaloids (schumannificine), isoquinoline alkaloids (michellamines), sulphated polysaccharides and polyphenolics, flavonoids, coumarins (glycocoumarin, licopyranocoumarin) phenolics (caffeic acid derivatives, galloyl acid derivatives, catechinic acid derivatives), tannins and triterpenes (glycyrrhizin and analogues, soyasaponin and analogues); 2) virus-cell fusion: lectins (mannose- and $\mathrm{N}$-acetylglucosamine-specific) and triterpenes (betulinic acid and analogues); 3) reverse transcription: alkaloids (benzophenanthridines, protoberberines, isoquinolines, quinolines), coumarins (calanolides and analogues), flavonoids, phloroglucinols, lactones (protolichesterinic acid), tannins, iridoids (fulvoplumierin) and triterpenes; 4) integration: coumarins (3-substituted-4-hydroxycoumarins), depsidones, 0-caffeoyl derivatives, lignans (arctigenin and analogues) and phenolics (curcumin); 5) translation: single chain ribosome inactivating proteins (SCRIP's); 6) proteolytic cleavage (protease inhibition): saponins (ursolic and maslinic acids), xanthones (mangostin and analogues) and coumarins; 7) glycosylation: alkaloids including indolizidines (castanospermine and analogues), piperidines (1-deoxynojirimicin and analogues) and pyrrolizidines (australine and analogues); 8) assembly/release: naphthodianthrones (hypericin and pseudohypericin), photosensitisers (terthiophenes and furoisocoumarins) and phospholipids. The target of action of several anti-HIV substances including alkaloids (O-demethyl-buchenavianine, papaverine), polysaccharides (acemannan), lignans (intheriotherins, schisantherin), phenolics (gossypol, lignins, catechol dimers such as peltatols, naphthoquinones such as conocurvone) and saponins (celasdin B, Gleditsia and Gymnocladus saponins), has not been elucidated or does not fit in the proposed scheme. Only a very few of these plant-derived anti-HIV products have been used in a limited number of patients suffering from AIDS viz. glycyrrhizin, papaverine, trichosanthin, castanospermine, $N$-butyl-1-deoxynojirimicin and acemannan.
\end{abstract}

Key words: Plant-derived products, antiviral activity, anti-HIV properties, anti-AIDS products.

Planta Medica 64 (1998) 97-109

(c) Georg Thieme Verlag Stuttgart · New York

\section{Introduction}

Acquired immunodeficiency syndrome (AIDS) is a pandemic immunosuppressive disease which results in life-threatening opportunistic infections and malignancies. Since a retrovirus, designated human immunodeficiency virus (HIV), has been clearly identified as the primary cause of this disease, numerous compounds including also plant-derived substances have been evaluated for their inhibitory effects on HIV replication in vitro (1).

According to De Clercq (2) the replicative cycle of HIV comprises ten steps that could be considered adequate targets for chemotherapeutical intervention. Most of the anti-HIV plant-derived compounds can be assigned to one of these ten classes of HIV inhibitors according to the stage at which they interfere with the HIV replicative cycle, i.e., adsorption, fusion, uncoating, reverse transcription, integration, DNA replication, transcription, translation, maturation and budding (assembly/ relase).

Some of the compounds that have been reported to inhibit HIV replication cannot be unequivocally allocated to one of the ten classes of HIV inhibitors primarily because their target of action has not been elucidated, e.g., alkaloids including papaverine and 0 -demethyl-buchenavianine, the polysaccharide acemannan, lignans such as intheriotherin $A$ and schisantherin $D$, gossypol and analogues, dehydrogenation polymers of cinnamic acid derivatives (similar to ligneous material), catechol dimers such as peltatols, naphthoquinones such as conocurvone and several saponins including Gleditsia saponin C and Gymnocladus saponin G. Other HIV inhibitors such as the naphthylisoquinolines, michellamines, 0 -caffeic acid and 0 -gallic acid derivatives seem to interact at multiple steps of the viral cycle, i.e., direct inactivation as well as inhibition of the HIV reverse transcriptase (RT) and/or HIV integrase (IN).

\section{Anti-HIV Plant-Derived Agents}

Alkaloids

A variety of alkaloids have been found to be inhibitory against HIV-infected cells. The flavonoid alkaloid, 0-demethyl-buchenavianine (1), isolated from Buchenavia capitata produces at subtoxic concentrations partial protection against the cytopathic effects of HIV in cultured human lymphoblastoid cells. In vitro tumour screening showed the compound to be cytotoxic 
(3). Isolated from the root bark of Schumanniophyton magnificum the chromone secondary amine, schumannificine (2), displayed the greatest activity against HIV, whereas potent anti-herpes simplex (anti-HSV) activity was observed for a number of its derivatives. The presence of a piperidine ring and unsubstituted hydroxy groups on the molecules seemed to favour the anti-HIV activity, which is considered to be due to irreversible binding to gp120 rather than inhibition of reverse transcriptase or protease (4).

The well-known benzylisoquinoline alkaloid, papaverine (3), has been shown to have a potent inhibitory effect on the replication of several viruses inlcuding cytomegalovirus (CMV), measles and HIV. It was suggested that the compound affected the expression of HIV proteins, especially of the envelope precursor protein gp120 (5).

In a report involving a limited number of patients, recovery of immunological cutaneous responsiveness was noted after administering papaverine orally for four weeks. This also was associated with a $50 \%$ improvement in their absolute $\mathrm{T}_{4}$ cells counts (6). Preliminary experiments indicate that the combination of suboptimal concentrations of both papaverine and AZT enhanced their inhibitory effects on HIV replication and HIV-induced cytopathic effects. The fact that papaverine has potent antiviral effects against CMV in vitro might make it attractive for use in combination therapy of AIDS patients with CMV disease.

Three novel anti-HIV atropisomeric naphthylisoquinoline alkaloid dimers, michellamines $A, B$ and $C$, have recently been obtained from the tropical liana Aristocladus korupensis from the rainforest of Cameroon. Despite relatively modest potency, all three compounds were capable of complete inhibition of the cytopathic effects of HIV-1 and HIV-2 on human lymphoblastoid target cells in vitro (7). Biochemical studies of the mechanism of action of the most potent and abundant member of the series, michellamine B (4), showed that this alkaloid acts both at an early stage of the HIV-life cycle by inhibiting reverse transcriptase (RT) as well as at later stages by inhibiting cellular fusion and syncyticum formation. Because of its unusual structure, broad range of anti-HIV activity, chemical stability and solubility, michellamine $B$ has been committed to preclinical drug development by the National Cancer Institute (NCI, USA) (8).

A number of alkaloids has been reported to inhibit HIVinfectivity by inhibiting the nitrogen-linked glycosylation process of HIV. Castanospermine (5), a tetrahydroxyindolizidine first isolated from the seeds of Castanospermum australe (9) and more recently from Alexia sp. (10) is a potent inhibitor of $\alpha$ - and $\beta$-D-glucosidases and several disaccharidases (11). It has been shown to display in vitro antiviral activity against retroviruses, including Rauscher murine leukemia (12), Moloney murine leukemia virus (13) and HIV (14). Castanospermine has been shown to inhibit the activity of $\alpha$-glucosidase I, the enzyme which is responsible for the cleavage of the terminal $\alpha$-glucose unit and thus initiates the trimming of the $\mathrm{N}$-linked oligosaccharides.

In addition to castanospermine also 6,7-diepicastanospermine (15) and several polyhydroxylated pyrrolizidine alkaloids such as australine (6) and analogues and alexine (16), showing varying degrees of inhibitory activity against glycosi- dases, have been isolated from Castanospermum australe and Alexia leopetala (10). The piperidine alkaloids including 1deoxynojirimicin (7) and $\alpha$-homonojirimicin (8) from Omphalea diandra (17) were also glycosidase inhibitors, whereas the analogue 1-deoxymannojirimicin (9) rather interfered with mannosidase (18). All these alkaloids inhibit HIV infectivity, albeit at relatively high concentrations $(0.1$ to $10 \mathrm{mM})$. The attenuated infectivity of HIV particles released from chronically infected cells that have been exposed to the glycosylation inhibitors is paralleled by reduced binding of these virions to the cells and, consequently, syncytium formation (19).

Castanospermine, when given orally at doses as high as 100 or $400 \mathrm{mg} / \mathrm{kg} /$ day, was found to inhibit Rauscher leukemia virus-induced splenomegaly by 37 and $78 \%$, respectively; however, when compared with AZT in the same murine system, castanospermine was less active and more toxic (12).

In patients, gastrointestinal side effects such as diarrhea, flatulence and abdominal pain have been noted with an $\mathrm{N}$ butyl analogue of 1-deoxynojirimicin (SC-48334) given orally at $1000 \mathrm{mg}$ every 8 hours (20). These problems would be caused by the inhibitory effect of SC-48334 on the intestinal $a$-glucosidases such as maltase and sucrase and might be overcome by prodrugs, i.e., $\mathrm{N}$-butyl-1-deoxynojirimicin-6phosphate (SC-49955) which do not inhibit gut $\alpha$-glucosidase. Admittedly, these prodrugs must be able to cross the intestinal barrier before they are hydrolysed so as to release the active compound $N$-butyl-1-deoxynojirimicin (2).

Out of 156 pure natural products which have been tested by Tan et al. (21) benzophenanthridine alkaloids such as fagaronine (10) and nitidine (11), which are known inhibitors of avian myeloblastosis virus RT (22) and protoberberine alkaloids such as columbamine (12), berberine (13), palmatine (14) and coralyne (15), which are known inhibitors of RNA tumour viruses (23) demonstrated potent anti-HIV-1 RT activity. Additional inhibitors found were the isoquinoline alkaloids psychotrine (16) and its 0 -methyl ether. All these alkaloids caused enzyme inhibition by interacting with the template primers, particularly those of the adenine-thymine base pairs (24). It was further shown that the inhibitory activity correlates well with the antileukemic effects in mice.

Recently, two known alkaloids viz. buchapine (17) and 3-(3methyl-2-butenyl)-4-[(3-methyl-2-butenyl)oxy]-2(1H)-quinolinone, isolated from Euodia roxburghiana were found to show inhibitory activity against HIV-1-RT and exhibit modest anti-HIV activity against HIV-1 in cultured human lymphoblastoid CEM-SS-cells (25).

\section{Carbohydrates}

Various sulphated polysaccharides have been found to be the anti-HIV active substances of many antivirally active plant extracts, e.g., Viola yedoensis (26), Prunella vulgaris (27), Alternanthera philoxeroides (28), all medicinal plants used in traditional Chinese medicine as anti-infectives. Other natural sources of anti-HIV sulphated polysaccharides include mosses and algae such as Chondrus crispus, Gigartina sp., Schizymena sp., and also bacteria, fungi, marine organisms and higher animals (1). Several naturally occurring polysaccharides such as dextran (18), dextrin (19), cyclodextrin, curdlan (20) and 
grifolan have been sulphated to variable degrees to afford sulphated analogues, which inhibit HIV replication in vitro at concentrations that are up to 10,000 -fold lower than the cytotoxic concentration.

These compounds are targeted at the interaction between the viral envelope glycoprotein gp 120 and the $\mathrm{CD}_{4}$ receptor, and as a consequence, they inhibit not only virus adsorption to the cells but also virus-induced syncytium (giant cell) formation. The inhibitory effects of dextran sulphate and its congeners on viral binding, viral replication and syncytium formation appear to be mediated by a specific interaction with the V3 region of gp120 (2). In addition, sulphated polysaccharides may also directly interfere with the binding of HIV particles to the heparin sulphate proteoglycan of the cell surface, whether or not this process occurs independently of, or cooperatively with, the viral envelope $-\mathrm{CD}_{4}$ receptor interaction (29).

Dextran sulphate is poorly adsorbed after oral administration and upon intravenous administration produces thrombocytopenia, so that there is little, if any, evidence for the in vivo efficacy of this compound and more generally of sulphated polysaccharides against HIV infection. Therefore one should consider their potential application in the (systemic) prophylaxis of HIV following an accidental needle stick injury or stab wound, i.e., conditions in which azidothymidine (AZT) has proved inefficacious and/or topical prophylaxis of HIV or HSV infection contracted through sexual intercourse (2).

It should be noticed that sulphated polymers owe their antiHIV activity to the presence of the sulphate groups, which in turn are responsible for the inhibition of virus-cell binding. In this sense, any compound could be turned into an anti-HIV agent targeted at virus-cell binding provided it contains the necessary hydroxy groups for attachment of the sulphate groups. In the last years several sulphated plant phenolics such as tannic acid sulphate, rutin sulphate, ellagic acid sulphate, (-)-epicatechin sulphate, (-)-epigallocatechin gallate sulphate and pentagalloylglucose sulphate have been synthesized (1). All these compounds were found to be inhibitory to HIV in vitro due to inhibition of viral adsorption to $\mathrm{CD}_{4}$-positive cells.

Preliminary in vivo studies in mice infected with HIV-1 revealed that HIV replication was significantly suppressed by sulphated pentagalloylglucose (21) (Y-ART-3), after intravenous administration of $4 \mathrm{mg} / \mathrm{kg}$. The compound also showed to be more stable in an effective form in the bloodstream than dextran sulphate (30).

In a pilot investigation using acemannan (Carrisyn), a polymannogalactoacetate from Aloe barbadensis, in the treatment of AIDS, McDaniel et al. treated a total of 53 patients over a period of 3 months. Acemannan treatment significantly improved clinical and laboratory parameters in these patients, while no prominent toxic effects were noted. The mode of action of acemannan against HIV infection has been seen as a combination of destruction of infected or defected cells due to activation of killer cells, production of non-infective, defective HIV virus, enhanced antibody production and increased host surveillance for other antigenic substances (31).

The mannose-specific plant lectins, e.g., from Cym:bidium hybrid, Epipactis helleborine, Hippeastrum hybrid and Listeria ovata and the $\mathrm{N}$-acetylgiucosamine-specific plant lectins, e.g., from Urtica dioica qualify as specific inhibitors of the virus cell-fusion process; they do not inhibit virus attachment to the cells, yet they block syncytium formation between HIVinfected cells and uninfected cells (32). Those plant lectins that inhibit syncytium formation also inhibit HIV replication, and it is likely that they intervene at the fusion step of HIV replication. This may also be the case for the mannose-specific lectins from Gerardia savaglia (33) and Machaerium sp. (34).

Mannose- and $\mathrm{N}$-acetylglucosamine-specific plant lectins may be assumed to interact with specific glycosylation sites within the viral envelope glycoproteins gp120 and/or gp41, particularly those sites that are rich in mannose or $\mathrm{N}$ acetylglucose. These plant lectins were also found to inhibit a number of other viruses, so that they should be further pursued for their therapeutic potential in the treatment of retro-, herpes- and myxoviruses in vitro (2).

\section{Coumarins}

Coumarins such as calanolides (35) and inophyllums (36) have been established as non-nucleoside specific inhibitors of HIV-1-RT. Calanolides A and B, isolated from the leaves of a tropical rainforest tree Calophyllum lanigerum collected in Sarawak, Malaysia, provided complete protection against the in vitro replication and cythopathicity of HIV-1 in lymphoblastic cells, but were inactive against HIV-2 or avian myeloblastosis virus (AMV). Further studies revealed that calanolides A and $B$ effectively inhibit the DNA-dependent DNA polymerase and RNA-dependent DNA-polymerase activities of HIV-1-RT, so that their interactions with HIV-1-RT may be distinct from that of other non-nucleoside HIV-1-RT inhibitors; in particular, a segment located between amino acids 225 and 425 in HIV-1-RT may be important for specifying susceptibility to these substances (37). Moreover, calanolide A was not only active against AZT-resistant G-9106 strain of HIV-1 but also against the pyridone-resistant A17 strain, the latter being highly resistant to previously known HIV-1 specific nonnucleoside RT inhibitors such as TIBO and nevirapine (35).

On the basis of these findings (+)-calanolide $A(\mathbf{2 2})$, being the most potent calanolide, has been committed to preclinical drug development by the US $\mathrm{NCl}$. As with many natural products, the procurement of adequate supplies of $(+)$ calanolide A for detailed biological evaluation has proved to be quite challenging, especially since it has been shown that only (+)-calanolide A and (-)-calanolide B, also known as costatolide (23), are potent HIV-1 inhibitors $\left(\mathrm{EC}_{50} 0.2\right.$ and $0.3 \mu \mathrm{M}$, respectively), while (-)-calanolide $\mathrm{A}$ and $(+)$-calanolide $B$ are inactive against the virus (38).

(+)-Calanolide A is only a minor compound of the leaves of Calophyllum lanigerum $(<1 \mathrm{mg} / \mathrm{g}$ extract) and although a synthesis of racemic calanolide A has been reported (39) a chiral synthesis is not yet available. Costatolide, however, was identified as the major active constituent from a tropical rainforest tree Calophyllum teysmannii being abundantly present in the latex ( $48 \%$ of latex extractables) (40). A related coumarin, soulattrolide (24), is also a major component (ca. $29 \%$ of latex extractables) in the latex of the same tree (41). In comparative anti-HIV tests, soulattrolide was found to mediate a response similar to calanolide $B$, but it was somewhat less potent than costatolide ( $\mathrm{EC}_{50} 0.34 \mu \mathrm{M}$ ). Consequently, 
<smiles></smiles>

O-demethyl-buchenavianine (1)<smiles>Cc1cc(=O)c2c(O)cc3c(c2o1)C1CCNC(=O)C1[C@H](O)C3</smiles>

Schumannificine (2)<smiles>COc1ccc(Cc2nccc3cc(OC)c(OC)cc23)cc1OC</smiles>

Papaverine (3)

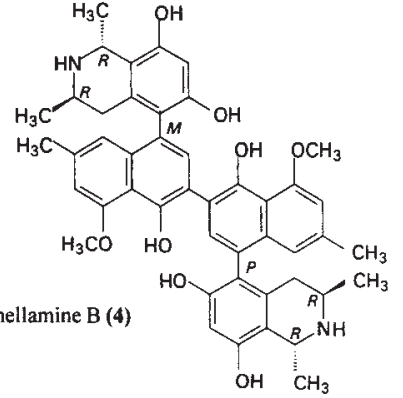<smiles>COc1cc2c[n+](C)c3c4cc(OC)c(OC)cc4ccc3c2cc1OC</smiles>

$\mathrm{R}_{1}=\mathrm{H} ; \mathrm{R}_{2}=\mathrm{CH}_{3}$ : Fagaronine (10) $\mathbf{R}_{1}, \mathbf{R}_{2}=-\mathrm{CH}_{2}-$ : Nitidine (11) $\mathrm{R}=\mathrm{CH}_{2} \mathrm{OH} ; 2 \alpha-\mathrm{OH}: \alpha$-homonojirimycin $\mathrm{R}=\mathrm{H} ; 2 \beta-\mathrm{OH}$ : 1-deoxymannojirimycin (9)<smiles>OC1CN2CCC(O)C(C1O)C2O</smiles>

Castanospermine (5)<smiles>OCC1C(O)C(O)C2C(O)CCN12</smiles>

Australine (6)<smiles>CC1NC(CO)C(O)C(O)C1O</smiles>

$=\mathrm{H} ; 2 \alpha-\mathrm{OH}: 1-$ deoxynojirimycin $(7)$

$\mathrm{R}_{1}=\mathrm{CH}_{3} ; \mathrm{R}_{2}=\mathrm{H}$; Columbamine (12) $\mathrm{R}_{1}, \mathrm{R}_{2}=-\mathrm{CH}_{2}-:$ : Berberine (13)

Coralyne (15)<smiles>CCC1CN2CCc3cc(OC)c(OC)cc3[C@H]2C[C@H]1CC1=NCCc2cc(O)c(OC)cc21</smiles><smiles>C=C(C)C(C)(C)C1C(=O)Nc2ccccc2C1=O</smiles>

$\mathrm{R}_{1}, \mathrm{R}_{2}=-\mathrm{CH}_{3}$ : Palmatine (14)

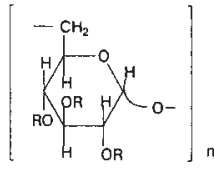

$\mathrm{R}=\mathrm{H}$ or $\mathrm{SO}_{3}$ Dextran sulphate (18)

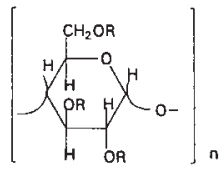

$\mathrm{R}=\mathrm{H}$ or $\mathrm{SO}_{3}^{-}$ Dextrin sulphate (19)

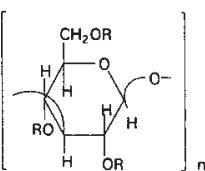

$\mathrm{R}=\mathrm{H}$ or $\mathrm{SO}_{3}$ Curdlan sulphate (20)
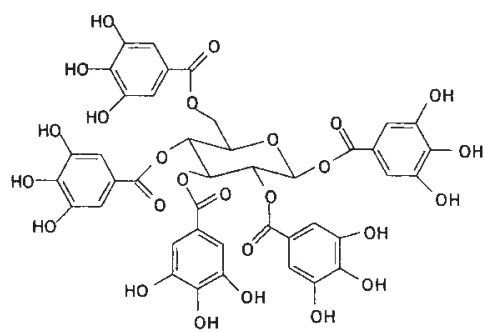

Pentagalloylglucose (21)<smiles>CCCc1cc(=O)oc2c3c(c4c(c12)OC(C)(C)C=C4)OC(C)[C@H](C)C3O</smiles>

(+)-Calanolide A (22)<smiles>CCCc1cc(=O)oc2c3c(c4c(c12)OC(C)(C)C=C4)OC(C)C(C)C3O</smiles>

(-)- Calanolide B (23) (Costatolide)<smiles></smiles>

Soulattrolide (24)<smiles>COc1c(CC=C(C)C)c(O)cc2oc(=O)c(-c3ccc(O)cc3O)cc12</smiles>

Glycycoumarin (25)

Fig. 1 Chemical structures of plant-derived anti-HIV substances 1-25.

costatolide and soulattrolide are possible alternatives to calanolide $A$, so that a sustainable source of natural product drug, non-destructive to the forest ecosystem, is now readily available (41).

Two coumarins isolated from Glycyrrhiza glabra namely glycocoumarin (25) and licopyranocoumarin (26) were found to inhibit giant cell formation in HIV-infected cell cultures without any observable cytotoxicity (42).

Semi-synthetic anticoagulants such as warfarin and phenprocoumon were found to strongly inhibit cell-free and cellmediated HIV-infection (43). It is now known that these anticoagulants inhibit the vitamin K-dependent conversion of 
prothrombine to an active form as well as the enzymatic activity of the serine-protease, thrombine. It was, therefore, not too surprising to find that these coumarins are competitive micromolar inhibitors of HIV-1 protease, an enzyme which is essential for proper virion assembly and maturation of HIV. Structural analogues of both compounds indicate that the pyran-2-one group, the 4-hydroxy group and substitution at the 3-position are all necessary for inhibitor activity (44). Recently, it was discovered that 3-substituted 4-hydroxycoumarin derivatives not only inhibit HIV-protease but also HIVintegrase (IN), an enzyme necessary for the integration of viral DNA (45), so that they may provide lead compounds for the development of novel antiviral agents, based upon the concurrent inhibition of two viral targets, HIV-1 integrase and protease (46).

\section{Flavonoids}

Mahmood et al. (47) tested a variety of flavones, flavanones and flavans against HIV-1 and HIV-2. As a group, the flavans exhibited the greatest selective anti-HIV-1 activity. The galloyl derivative, (-)-epicatechin-3-0-gallate (27) consistently exhibited the highest activity, $\mathrm{EC}_{50}$ of $1 \mu \mathrm{g} / \mathrm{ml}$ and selectivity index $(\mathrm{SI})>100$, and was somewhat more active than (-)-epicatechin. Differences between isomers were noted in the lower activity of (-)-epigallocatechin in contrast to (+)-gallocatechin.

Of seventeen flavones only myricetin $(\mathrm{SI}=20$ ) and the 3-Oglycosides of kaempferol (28), quercetin (29) and myricetin (30) caused significant inhibition of HIV-1 infection at nontoxic concentrations. None of the flavanones selectively inhibited HIV-1 replication. On the contrary, these compounds were generally more cytotoxic than the flavan and flavone derivatives studied. The inhibitory action of these substances was shown to be non-specific and was principally due to a more selective interaction with gp120. In this respect the anti-HIV action of these flavonoids is similar to the actions of polyanionic compounds such as sulphated polysaccharides and various tannins, which interact irreversibly with gp 120 to block virus infection (47).

In addition to two coumarins, also three flavonoids with in vitro anti-HIV activity namely licochalcone A (31), isolicoflavonol (32) and glycyrrhizoflavone (33), have been isolated from Glycyrrhiza glabra. They seem to block giant-cell formation in HIV-infected cell cultures as well (42).

One flavone, i.e., baicalein (34) and three flavonols including quercetin (29), myricetin (30) and quercetagetin (35) have been shown to inhibit in vitro RTs of certain retroviruses including Rauscher murine leukemia virus (RLV) and HIV as well as cellular DNA polymerases $(48,49)$. Comparative studies with other flavonoids revealed that the presence of both the double bond between positions 2 and 3 of the flavonoid pyrone ring, and the three hydroxy groups introduced on positions 5, 6 and 7 (i.e. baicalein) were a prerequisite for the inhibition of RT-activity. Removal of the 6-hydroxy group of bacalein required the introduction of three additional hydroxy groups at positions $3,3^{\prime}$ and $4^{\prime}$ (quercetin), to afford a compound still capable of inhibiting the RT-activity. Quercetagetin which contains the structures of both baicalein and quercetin, and myricetin which has the structure of quercetin with an additional hydroxy group on the 5 ' position also proved strong inhibitors of RT activity. The inhibition by baicalein of RT is highly specific, whereas quercetin and quercetagetin were strong inhibitors of DNA polymerase $\beta$ and DNA polymerase I, respectively. Myricetin was also a potent inhibitor of both DNA polymerase $\alpha$ and DNA polymerase I. These facts suggested that baicalein might be less toxic to the retroviruses-infected host cell DNA and RNA polymerases than the flavonols (48). These results were confirmed by Kusumoto et al. (50), who tested one hundred and ninety flavonoids for their inhibitory effects on avian myeloblastosis virus (AMV) RT. Quercetagenin (30), 6-hydroxyluteolin (36), pedalitin (37) and 6-hydroxykaempferol (38) were the most potent inhibitors with $\mathrm{IC}_{50}<10 \mu \mathrm{M}$. Five other flavonoids including baicalein (34), baicalin methyl ester, scutellarein (39), myricetin (30) and gossypetin (40) gave $\mathrm{IC}_{50} \mathrm{~s}$ between 35 and $200 \mu \mathrm{M}$. All these flavonoids did not show any significant effect on DNA-polymerase I. Spedding et al. (51) found the biflavonoid amentoflavone (41) besides scutellarein (39) and quercetin (29) to be the most active inhibitors of AMV-RT, Rous-associated virus-2 (RAV-2)-RT and Moloney murine leukemia virus (MMLV)-RT out of eighteen flavonoids tested.

A new flavanone-xanthone glucoside, swertifrancheside (42), isolated from Swertia frachetiana was found to be a potent inhibitor of DNA polymerase activity of HIV-1 RT with $\mathrm{IC}_{50}$ of $43 \mu \mathrm{m}$ (52).

\section{Lignans}

Two lignanolides of the dibenzylbutyrolactone type, (-)arctigenin (43) and (-)-trachelogenin (44), isolated from Forsythia intermedia and Ipomoea cairica, respectively, have been shown to inhibit replication of HIV-1 in infected human cell systems (53). These compounds were found to suppress the integration of proviral DNA into cellular genome (54). More detailed experiments with purified HIV-1 integrase, however, showed (-)-arctigenin to be inactive in the cleavage (3'-processing) and integration (strand transfer) assays. However, the semisynthetic 3-0-demethylated congener characterised by a catechol structure, exhibited a total inhibition of the 3'-processing step as well as of the strand transfer step at $100 \mu \mathrm{M}$ with $\mathrm{IC}_{50}$ values of $21.4 \pm 15.0$ and $5.4 \pm 4.0 \mu \mathrm{M}$, respectively. It was subsequently shown that the binding site of this compound resides in the catalytic domain (55).

Recently, the dibenzocyclooctadiene lignans, interiotherin A and schisantherin D were isolated as the anti-HIV principles from Kadsura interior, inhibiting HIV-replication with $\mathrm{EC}_{50}$ values of 3.1 and $0.5 \mu \mathrm{g} / \mathrm{ml}$, respectively. The corresponding therapeutic indices (Ti) were 13.2 and 50.6, respectively (56).

Numerous reports claim that an aqueous-alkali treatment of previously extracted pine cones affords after fractionation a "lignin-related" isolate, containing high molecular weight substances, i.e., KS-6 and KS-7 having antiviral and antitumour activities (57). These substances also had immunopotentiating effects and induced macrophage differentiation, whereas cytotoxicity was relatively low (58). Recently, Eberhardt and Young (59) provided the first definitive evidence by thioacidolysis for a phenylpropanoid, i.e., lignin component in this isolate which may provide the observed anti-HIV-1 activity for this substance. 
Also dehydrogenation polymers of cinnamic acid derivatives, which seem to be similar to ligneous material, and can be synthesised in the presence of peroxydase and hydrogen peroxide (MW $=800-150,000)$ show anti-HIV activity by preventing the binding of gp120 to the $\mathrm{CD}_{4}$ receptor (60).

\section{Phenolics}

The caffeoylquinic acids, 3,4,5-tri-0-caffeoylquinic acid (3,4,5TCQA) (45) and 4,5-di-O-caffeoylquinic acid (4,5-DCQA), isolated from Securidaka longipedunculata and some galloylquinic acids such as 3,4,5-tri- 0 -galloylquinic acid (3,4,5-TGQA) from Guiera senegalensis are selective inhibitors of HIV with SI of 300,67 and 94 , respectively (61).

Previously, similar phenolics including 1,3,4-TGQA (46), 3,5-0digalloylshikimic acid (3,5-DGSA) (47), 3,4,5-TGSA (62) and several tetragalloylquinic acids (63) were shown to selectively inhibit HIV-replication and to inhibit HIV-RT in vitro. However, their ability to inhibit cellular DNA polymerases was inconsistent with specific inhibition of the virus enzyme. It was then also reported that inhibition of HIV-RT in vitro by caffeoyl- and galloylquinic acid is non-specific and that inhibition of virus infection is due to interaction of the compounds with gp 120 , preventing virus binding to the $\mathrm{CD}_{4}$ receptor (61). The same mode of action was also found for the anti-HIV active monosodium and monopotassium salts of isomeric caffeic acid tetramers, isolated from Arnebia euchoma (64).

The antiviral action of these compounds is not peculiar to HIV since they exhibit even greater activity against HSV-1 infection. Their ability to bind irreversibly to gp 120 and inactivate virus infectivity make these agents suitable candidates for investigating their potential in counteracting sexual transmission of HIV and HSV infections.

Recently, it has been shown that 1,5-DCQA, 4,5-DCQA, 3,5DCQA and L-chicoric acid are potent inhibitors of HIV-1 IN in vitro and HIV-1 replication in vivo (65). In general HIV-IN inhibitors may be described as consisting of two aryl units, one of which contains the 1,2-dihydroxy (catechol) pattern, separated by an appropiate linker segment. Examples of this are the flavones including quercetin, caffeic acid phenyl ethyl ester (CAPE) and analogues, bis-catechols such as $\beta$-conidendrol and the aforementioned arctigenin-based compounds. Curcumin, which bears strong similarity to CAPE, affords an example of a moderately potent HIV-1-IN inhibitor which does not contain the catechol pattern $(66,67)$. Other HIV-1-IN inhibitors include the depsidone virensic acid and its methyl ester derivative granulatine, which have been used by means of molecular modeling and three-point pharmacophore searching of a 3D-database to select a small set of structurally diverse HIV-1-IN inhibitors from a large collection (68).

Three new prenylated catechol dimers, namely peltatols $A$ (48), B and C have been isolated from the tropical shrub Pothomorpha peltata, growing in the Dominican Republic. These compounds inhibit HIV-1 induced cell killing at subtoxic concentrations of $1-10 \mu \mathrm{g} / \mathrm{ml}$. The monomeric catechol derivative 4-nerolidylcatechol was inactive in the anti-HIV screen, however, it did weakly block phorbol receptor binding (69).

Gossypol (49), a polyphenolic aldehyde extracted from cottonseed is active against enveloped viruses, including HIV
(70). Evaluation of the two pure enantiomers showed the (-)enantiomer of gossypol to be very inhibitory $\left(\mathrm{EC}_{50}=1.0-\right.$ $5.0 \mu \mathrm{M})$, whereas the (+)-enantiomer was much less active $\left(\mathrm{EC}_{50}=50-100 \mu \mathrm{M}\right)$. Since gossypol was quite cytotoxic in cell cultures, several analogues were prepared in order to increase the SI (71). Although differences in inhibition of cytotoxicity were found, none was of the magnitude to justify further study, so that its potential application is only to be considered as an external virucidal agent.

Other plant-derived phenolics with anti-HIV RT activity include several phloroglucinol derivatives such as mallotojaponin (50) and mallotochromene (51), both isolated from the pericarps of Mallotus japonicum (72) and an aliphatic $\alpha$ methylene- $\gamma$-lactone, protolichesterinic acid (52) isolated from the lichen Cetraria islandica (52).

\section{Proteins}

Several plant single chain ribosome inactivating proteins (SCRIPs) cleave the eukaryotic ribosomal 28S RNA and display a powerful antiviral action against both DNA and RNA viruses (73). Pokeweed antiviral protein (PAP) derived from Phytolacca americana and trichosanthin, referred to as GLQ233 and isolated from the root tubers of Trichosanthes kirilowii, were found to inhibit HIV replication in acutely and chronically infected lymphocytes and macrophages $(74,75)$. Other SCRIPs tested that also have inhibitory effects on HIV-1 replication are TAP or Trichosanthes antiviral protein, a $29 \mathrm{kDa}$ protein also isolated from Trichosanthes kirilowii and MAP or Momordica antiviral protein from Momordica charantia. Although it is assumed that these compounds owe their anti-HIV activity to their "SCRIP" effect, namely cleavage of ribosomal 28S RNA and thus abrogation of polypeptide chain elongation, a causal link between SCRIP and anti-HIV activity has not been established (2).

Recently, Girber et al. (76) suggested that the claimed antiHIV properties of SCRIPs might be due to a topoisomerase activity (77) and/or an inhibitory activity on the HIV-1 integrase (78). Despite its overt toxicity to host cells, GLQ233 has been tested in HIV-1 positive patients (phase I and II clinical trials) (79). Immunogenenicity and potential anaphylactic reactions in animals and patients receiving multiple doses of protein drugs like GLQ233 have been a matter of concern.

Immunotoxins prepared from ricin, a toxic two chain RIP isolated from Ricinus communis, have been used in the clinical treatment of cancer patients. Later on, immunoconjugates containing monoclonal antibodies specific for the envelope protein gp41 of HIV linked to the ricin A chain have been shown to kill HIV-infected T cells and monocytes (80). Inhibition of protein synthesis, cell growth and viral production was also observed when a conjugate with antibody against the gp120 glycoprotein was tested in HIV-infected cells (81).

\section{Quinones/Xanthones}

A novel trimeric naphthoquinone, conocurvone (53) has been isolated as an active anti-HIV constituent of an extract from an endemic Australian shrub Conospermum sp. This compound prevented the cytopathic effects and replication of HIV in human T-lymphoblastic cells (CEM-SS) over a concentra- 


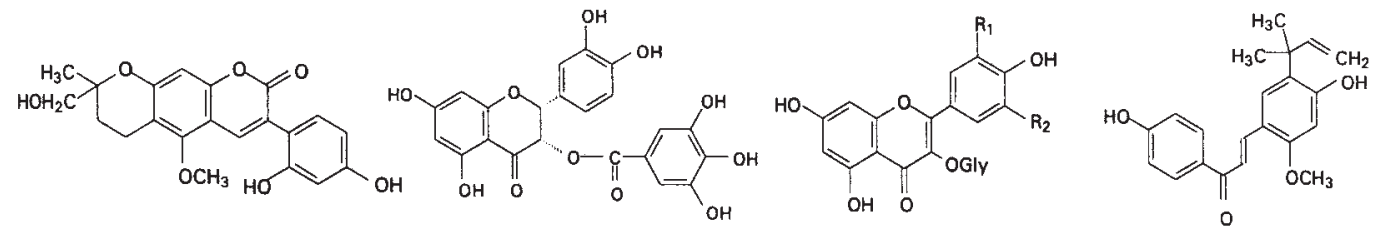

Licopyranocoumarin (26)

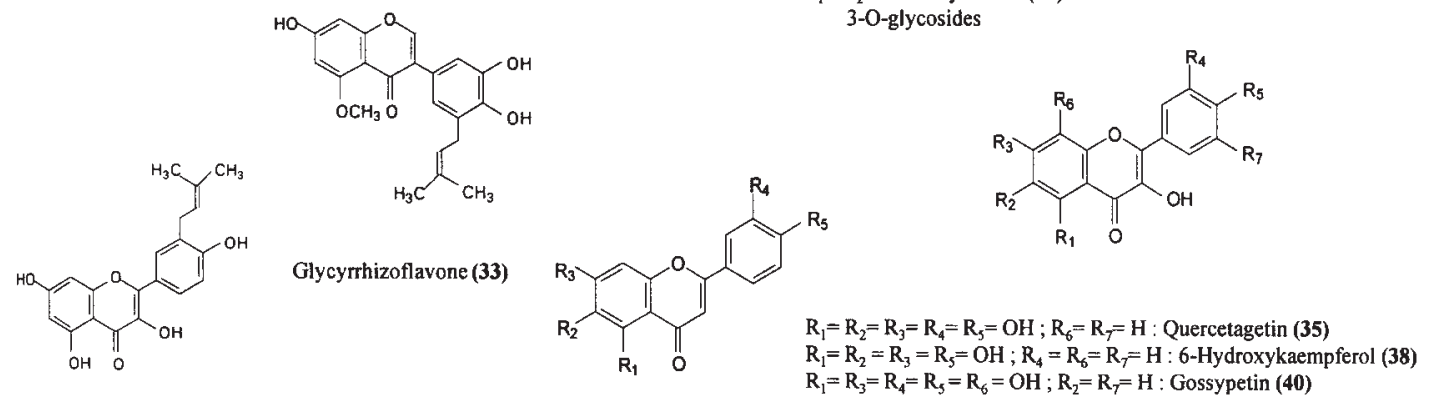

Isolicoflavonol (32) $\quad \mathbf{R}_{\mathbf{1}}=\mathbf{R}_{2}=\mathbf{R}_{3}=\mathrm{OH} ; \mathbf{R}_{4}=\mathrm{R}_{5}=\mathrm{H}$ : Baicalein (34)

$R_{1}=R_{2}=R_{3}=R_{4}=R_{5}=O H$ : 6-Hydroxyluteolin (36)

$R_{1}=R_{2}=R_{3}=R_{9}=O H ; R_{4}=\mathrm{CH}_{3}$; Pedalitin (37)<smiles></smiles>

$\mathbf{R}_{1}=\mathbf{R}_{2}=\mathbf{R}_{3}=\mathbf{R}_{5}=\mathbf{O H} ; \mathbf{R}_{4}=\mathrm{H}$ : Scutellarein (39)

Amentoflavone (41)

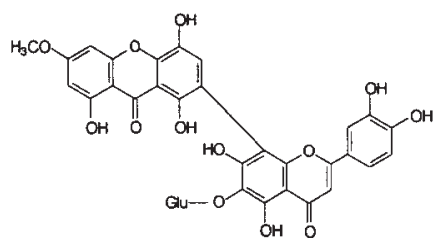

Swertifrancheside (42)

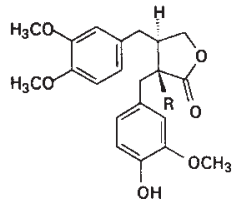

$\mathrm{R}=\mathrm{H}:(-)$-Arctigenin (43)

$\mathrm{R}=\mathrm{OH}:(-)$-Trachelogenin (44)<smiles>[R6]C1CC([R])(C(=O)O)CC(O)C1O</smiles>

A $\mathrm{OH}$<smiles>O=C(Br)c1cc(O)c(O)c(O)c1</smiles>

A: 1, 3, 4-tri-O-galloylquinic acid (46)

B : 3, 5-di-O-galloylshikimic acid (47)

C : 3,4,5-tri-O-caffeoylquinic acid (45)<smiles>[R9]O[C@H]1C[C@](O)(C(=O)O)C[C@H](O[R6])[C@@H]1O</smiles>

C

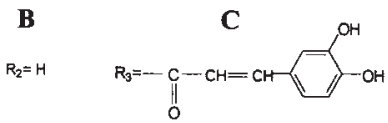

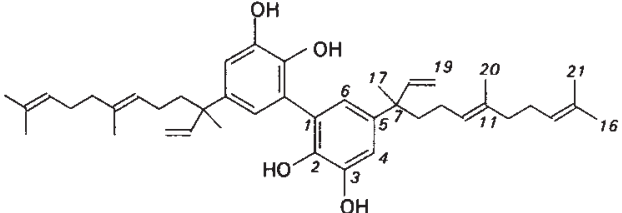

Peltatol A (48)<smiles>COc1c(C)c(O)c(C(C)=O)c(O)c1Cc1cc(CC=C(C)C)c(O)c(C(C)=O)c1O</smiles><smiles>C=C1C(=O)O[C@@H](CCCC)[C@@H]1C(=O)O</smiles><smiles>Cc1cc2c(C(C)C)c(O)c(O)c(C=O)c2c(O)c1-c1c(C)cc2c(C(C)C)c(O)c(O)c(C=O)c2c1O</smiles>

Mallotojaponin (50)

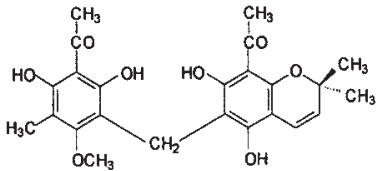

Mallotochromene (51)

Gossypol (49)

$26-52$.

tion range of $0.02-50 \mu \mathrm{M}$. The related naphthoquinone monomer teretifolione was also isolated from the same extract, but was inactive against HIV (82).

The naphthodianthrones, hypericin (54) and pseudohypericin (55), which occur in plants of the Hypericum family, are highly effective in preventing viral-induced manifestations that follow infection with a variety of retroviruses in vitro and in vivo. Although these compounds are photodynamic agents causing hypericism in cattle ingesting large amounts of Hypericum sp. on pastures, adverse effects were not recorded 
at the experimental doses of hypericin in in vivo tests in mice (83).

These compounds would have the capacity to block viral assembly in (or release from) infected cells as well as directly inactive properly assembled (or released) virions (84). Visible light is essential for all of the antiviral effects of these compounds. Upon illumination with visible light, these compounds inactivate enveloped, but not unenveloped viruses and thus act as virucidal agents (85). Only when the concentration of hypericin approached the cytotoxic level was there an apparent light-independent antiviral effect (86). Hypericin is known to form triplets and to generate singlet oxygen with high efficiency, which may play a role in the antiviral activity of this compound, but as has been shown recently it does not play a major role (87).

Hypericin inhibits also protein kinase C (PKC) activity and epidermal growth factor receptor tyrosine kinase activity. While hypericin may be a suitable agent for photodynamic inactivation of enveloped viruses in blood and blood products, it is hard to conceive how this compound could be useful in the systemic treatment of HIV-infected patients (2).

Recently, two related xanthones, namely mangostin and $\gamma$ mangostin, isolated from Garcinia mangostana, have been found as active constituents against HIV-1 protease. The type of inhibition by both compounds is non-competitive (88).

\section{Phospholipids}

Several phospholipid formulations including phosphatidylcholine, phosphatidylinositol and phosphatidylethanolamine, purified from soy bean, exhibited anti-HIV activity in different test systems at relatively high but apparently non-toxic concentrations $\left(\mathrm{IC}_{50}=16-20 \mu \mathrm{M}\right)$. Phospholipids containing two sites of unsaturation in the fatty acid moiety are active while phospholipids containing only fully saturated fatty acids did not exhibit any anti-HIV activity (89). The mode of action of these compounds may relate to the accumulation of toxic metabolic products into the membranes of the virus after the hydrolysis of these compounds by phospholipase A$2(90)$.

\section{Photosensitisers}

Photosensitisers of a variety of chemical families have demonstrated clearly that, when in association with cells or cell membranes and when activated at an appropiated wavelength of light, a photodynamic mechanism is initiated which usually results in the destruction of the cell. The mechanism by which the cell destruction occurs is thought to involve mainly the generation of singlet oxygen which interacts with cellular components, including lipids and proteins. In the case of many photosensitisers, which have been tested both in vitro and in vivo, the photodynamic attack appears to take place mainly in association with membranes. Membrane disruption with concomitant leakage of intracellular material and loss of cell function leads to cell death (82).

Several classes of photosensitisers including terthiophenes, i.e., sulfur-containing heterocyclic compounds that are widely distributed among species of the Asteraceae, furoisocoumarins and porphyrins have been evaluated for activity against HIV.
The furoisocoumarin, coriandrin (56), isolated from Coriandrum sativum, the thiarubines $\mathrm{A}(57)$ and $\mathrm{D}$ (dithiocyclohexadienes) obtained from Chenactis douglasii and $\alpha$-terthienyl ( $\alpha$ T) (58), a trithiophene obtained from Tagetes sp., showed prominent anti-HIV activity in the presence of long wavelength light (UVA, $320-400 \mathrm{~nm}$ ). The compounds had little or no activity in visible light or in the dark. The anti-HIV effect was UVA-dose dependent and was proportional to the concentration of the substances, according to several parameters of virus infectivity and replication. The efficacy of all products was decreased to some extent by the presence of bovine or human serum in the reactions, which suggests that the compounds may have a certain affinity for certain protein or lipid materials $(91,92)$.

Of these photodynamic agents $\alpha$-terthienyl is the most potent antiviral phytochemical and should be evaluated further for its potential use in the decontamination of blood products, where a number of viruses, including retroviruses, constitute potential hazards (86).

\section{Tannins}

Several of the virucidal plant compounds are tannins or related phenolic substances, which are often responsible for the virucidal effects in several viral systems, found for tea as well as juices and beverages prepared from common fruits (93). In general, it is believed that polyphenols act by associating with proteins of viral particles and/or host cell surfaces, resulting in a reduction or prevention of viral adsorption.

Several hydrolysable tannins show an anti-HIV activity which is mediated, at least, in part by inhibition of HIV adsorption to the cells. Examples of these tannins are chebulagic acid (59), punicalin and punicalagin from Terminalia chebula (94), gemin D (60) from Geum japonicum, nobotanin B (61) from Tibouchina semidecandra, camelliin B (62) from Camellia japonica and trapanin B (63) from Trapa japonica. However, it should be noted that even at high concentrations these tannins did not completely inhibit HIV binding. It was subsequently found that the dimeric hydrolysable tannins are potent inhibitors of poly (ADP-ribose) glucohydrolase, an enzyme that plays a regulatory role in gene transcription (95).

Kakiuchi et al. (96) found that hydrolysable tannins including gallotannins and ellagitannins were potent inhibitors of RT from avian myeloblastosis virus (AMV) due to an interference of the template-primer-enzyme nucleotide complex. Dimeric ellagitannins, including among others coriariin A (64) and agrimoniin (65) were more effective inhibitors than monomeric ellagitannins, and trigalloylglucose and tetragalloylglucose were less effective than the gallotannins with a larger number of galloyl residues such as hepta- and octagalloylglucoses. Dimeric ellagitannins such as oenothein B were also found to inhibit replication of HIV (97). The inhibitory action was ascribed to inhibition of both viral adsorption and RTinhibitory activity. Mouse sera obtained after oral administration of oenothein B also inhibited HIV and HSV replications. Other inhibitors of HIV-RT are the gallotannins punicalin, punicacortein, sanguin $\mathrm{H}-11,(62)$ and shephagenins $A$ and $B$ (98), ellagic acid (66) (99) and digallic acid (67) (100).

Investigation of eighteen condensed tannins on RT from avian myeloblastosis virus showed galloylated catechin and epica- 

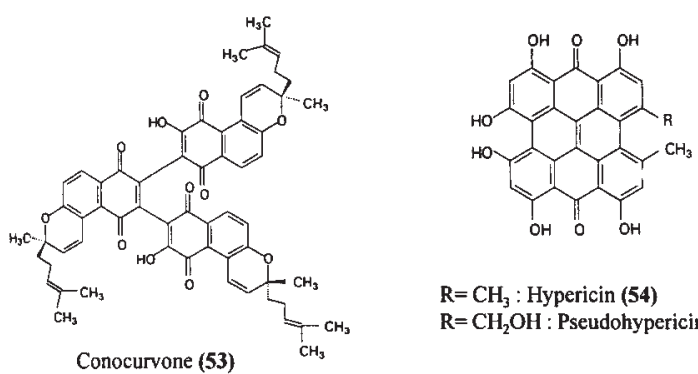

$\mathrm{R}=\mathrm{CH}_{3}:$ Hypericin (54) $\mathrm{R}=\mathrm{CH}_{2} \mathrm{OH}:$ Pseudohypericin (55)

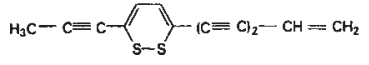

Thiarubrine A (57)
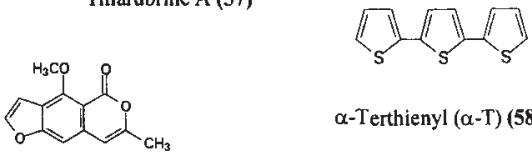

$\alpha$-Terthienyl $(\alpha-T)(58)$

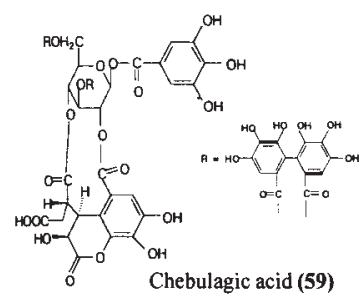

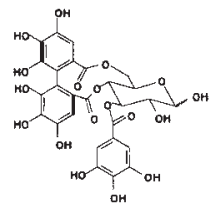

Gemin D (60)
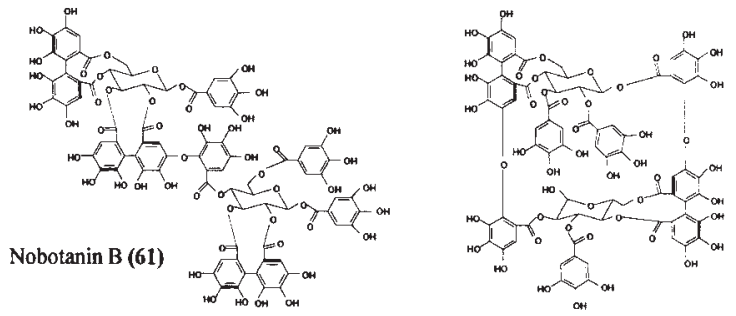

Camelliin B (62)

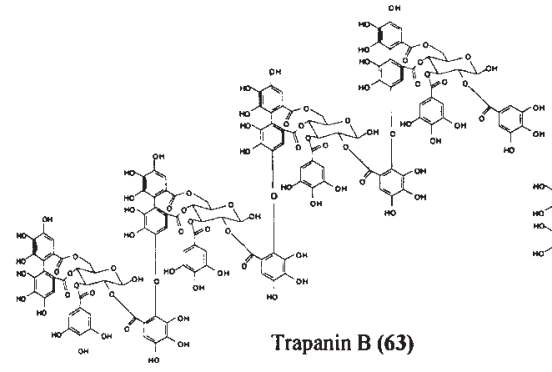

Coriariin A (64)
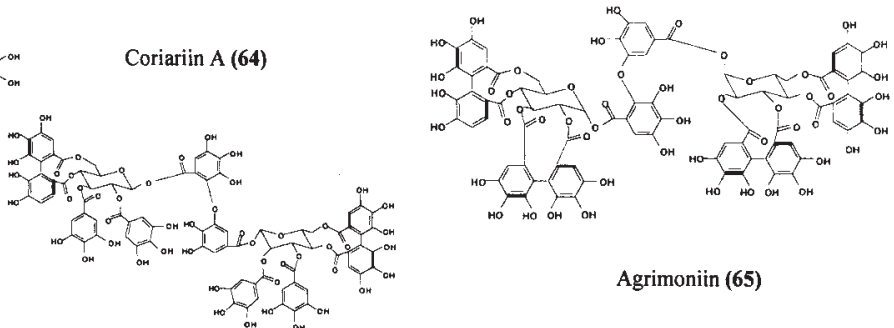

Agrimoniin (65)

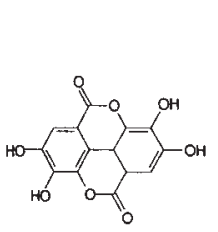

Ellagic acid (66)

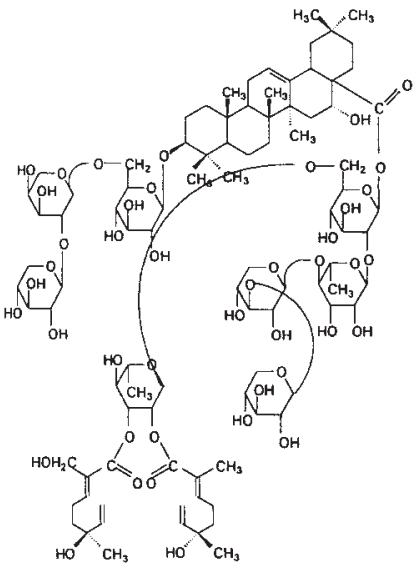

Gleditsia saponin C (71)

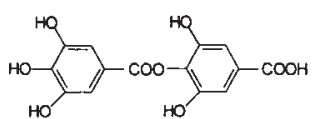<smiles>Oc1cc(O)c2c(c1)Oc1c(c(O)cc(O)c1C1c3c(O)cc(O)cc3C(O)C1O)OC(c1ccc(O)c(O)c1)C2O</smiles>

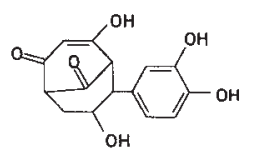

Catechinic acid (69)

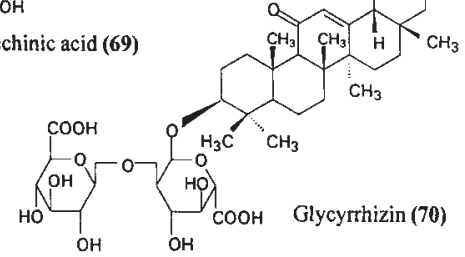

Procyanidin $\mathrm{B}_{2}(\mathbf{6 8})$

Fig. 3 Chemical structures of plant-derived anti-HIV substances 53-73.

techin as well as non-galloylated tetramers, trimers and dimers to be potent inhibitors. The mode of the inhibition of procyanidin $B_{2}(\mathbf{6 8})$ was similar to that of the ellagitannins, i.e., an inhibition of nucleic acid enzyme complex formation. The presence of galloyl, pyrogallol and hexahydroxydiphenoyl groups which have an ortho-trihydroxy substitution pattern was all beneficial for the inhibition of RT (101).

Interestingly, it was found that the methanolic extract of Combretum micranthum is only active against enveloped 
viruses such as HIV and HSV when it is kept for seven days. On standing the inactive condensed tannins are cleaved under alkaline conditions to their monomers, which undergo a spontaneous intramolecular rearrangement into catechinic acid (69). Auto-oxidation in alkaline medium of catechinic acid gives rise to the formation of polyphenol radicals which undergo a variety of reactions to give antivirally active polymers through $\mathrm{C}-\mathrm{C}$ and $\mathrm{C}-\mathrm{O}$ couplings. These oxidised polymerisates are named auto-oxidised catechinic acid (AOCA) and can also be prepared by bubbling air through an alkaline solution of catechinic acid at different temperatures (102).

AOCA, especially the polymers with $M_{\mathrm{r}}$ between 10,000 and 30,000 , showed prominent anti-HIV properties with low cytotoxicity, probably by acting in the first stage of infection and thereby inhibiting virus penetration into the cells. These polymers were also found to be active in vitro against HSV-1 and HSV-2 (102).

\section{Terpenes}

Glycyrrhizin (70), one of the main saponins of Glycyrrhiza glabra inhibits the growth of a number of DNA and RNA viruses including HIV 1 in vitro (103). In Japan, glycyrrhizin has been studied in AIDS patients. It was claimed that, when given orally to asymptomatic HIV carriers, the substance delayed the progression of symptoms related to HIV. It was also claimed that, when administered intravenously for a period of more than a month, to hemophilics with AIDS, viral antigen considerably decreased, suggesting that glycyrrhizin might inhibit HIV replication in vivo. In another claim simultaneous administration of the compound appeared to decrease the adverse reactions of zidovudine (104).

Recently, glycyrrhizin was tested in a murine AIDS model (MAIDS) consisting of mice inoculated with LP-BM5 murine leukemia virus. The results of this in vivo test suggest that treatment of MAIDS mice with glycyrrhizin supplemented with glycine and cysteine is effective in preventing the progression of the disease in some of the infected mice (105).

Investigations on the mechanism of action of glycyrrhizin suggested that the compound, being a polyanionic substance, interferes with virus adsorption, which is further complemented by an inhibitory effect on PKC. This enzyme seems to be required for the binding of HIV 1 particles to the cellular $C_{4}$ receptors (106).

Although glycyrrhizin itself did not show any significant effect on viral reverse transcriptase its sulphate was an inhibitor. This substance was estimated to be four times as potent as its parent natural compound in anti-HIV studies (107).

Also other saponins including saponin $B_{1}$ from soybean (108), Gleditsia saponin C (71) from Gleditsia japonica and Gymnocladus saponin G (72) from Gymnocladus chinensis (109) exhibited potent anti-HIV effects in vitro. Preliminary structure-activity correlation showed that the corresponding prosapogenins of Gymnocladus saponin $G$ and Gleditsia saponin C were not active, which suggests that the monoterpenyl moieties present in both saponins play an important role in modulating the anti-HIV activity of these compounds (109).

Three saponins viz. $2 \alpha, 19 \alpha$-dihydroxy-3-oxo-12-ursen-28-oic acid (73), ursolic acid (74) and maslinic acid (75) from Geum japonicum showed potent inhibitory activity against HIV-1 protease (110). The saponin, celasdin B, was found to exhibit anti-HIV replication activity in $\mathrm{H}_{9}$ lymphocyte cells with an $\mathrm{EC}_{50}$ of $0.8 \mu \mathrm{g} \mathrm{m}^{-1}(111)$.

Recently the known triterpenoids betulinic acid (76) and platanic acid (77), isolated from the leaves of Syzygium claviflorum, have been identified as potent and selective HIV1 inhibitors (112). These compounds are not active against HIV-2 and apparently targeted at a post-binding virus-cell

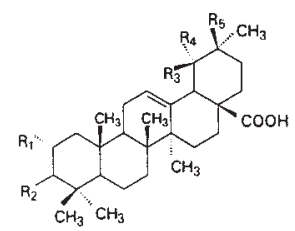

$\mathrm{R}_{1}=\mathrm{R}_{4}=\mathrm{R}_{5}=\mathrm{H} ; \mathrm{R}_{2}=\beta-\mathrm{OH}, \mathrm{R}_{3}=\mathrm{CH}_{3}$ Ursolic acid (74)

$\mathrm{R}_{1}=\mathrm{R}_{3}=\mathrm{H} ; \mathrm{R}_{2}=\alpha-\mathrm{OH}, \mathrm{R}_{3}=\mathrm{CH}_{3} ; \mathrm{R}_{4}=\mathrm{OH}$ Maslinic acid (75)

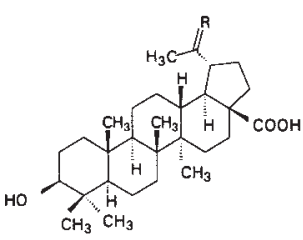

$\mathrm{R}=\mathrm{H}, \mathbf{H}:$ Betulinic acid (76) $\mathrm{R}=\mathrm{O}$ : Platanic acid (77)<smiles></smiles>

Fulvoplumierin (78)

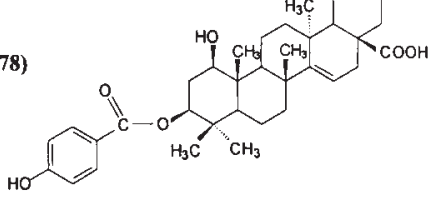

1- $\beta$-hydroxyaleuritolic acid 3-p-hydroxybenzoate (79)<smiles>CC(N)C1[C@H](O)CC2(C)C3CCC4C(N)CCCC4(C)C3CCC12C</smiles>

Cyclobuxamine $\mathbf{H}(\mathbf{8 2})$

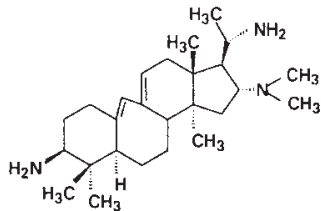

Buxamine E (81)

Fig. 4 Chemical structures of plant-derived anti-HIV substances 74-82. 
fusion step, required for virus entry into the cells (113). Extensive structure-activity relationship studies were carried out leading to the synthesis of a series of $\varpi$-aminoalkanoic acid derivatives of betulinic acid. The anti-HIV 1 activity of several members of this new series was found to be in the nanomolar range in CEM-4 and MT-4 cell cultures (114).

Further mechanistic studies ruled out an interference with the binding of gp120 in the $\mathrm{CD}_{4}$ molecule or in a cellular context. Moreover, betulinic acid derivatives were able to block efficiently syncyticum fcrmation of $\mathrm{CD}_{4}$ cells mediated by the HIV- 1 envelope glycoproteins, which confirm the interaction of these substances with the post-binding viruscell fusion process (115).

Plant-derived terpenic RT-inhibitors that have been reported are the iridoid, fulvoplumierin (78) (21) and the triterpenes, $1-\beta$-hydroxyaleuritolic acid-3-p-hydroxybenzoate (79) from Maprounea africana (52), and nigranoic acid (80) from Schisandra sphaerandra (116).

Also several steroidal alkaloids such as buxamine $\mathrm{E}(\mathbf{8 1})$ and cyclobuxamine $\mathrm{H}$ (82) from Buxus sempervirens have been shown to inhibit HIV-1 RT as well as TNF (1).

\section{Conclusion}

As evident from this review, there is now considerable evidence emerging not only from the many reports and publications but also from controlled clinical studies of the potential of plant-derived substances as important leads for the development of antiviral and/or virucidal drugs against viral infections caused by HIV.

Only a few experimental studies to discover anti-HIV agents from medicinal plants and other natural products are in progress. The major programme of this type is being carried out at the U.S. National Cancer Institute. In this programme about 4500 plant samples are currently screened per year for in vitro anti-HIV activity, based on a random selection of plants. These studies have resulted already in the isolation of several new leads of promising natural anti-HIV compounds such as naphthylisoquinoline din:ers, dipyranocoumarins, prenylated catechol dimers, and naphthoquinone trimers. Some of these leads viz. (+)-calanolide $A$ as inhibitor of reverse transcriptase and michellanine $B$ as inhibitor of cellular fusion and syncytium formation have been committed to preclinical drug development.

Other interesting leads for the development of antiviral drugs include a large variety of secondary plant metabolites that exhibit competitive in vitro and in vivo antiviral activities comparable with those found for synthetic counterparts which are in various stages of development. These natural products have shown to interfere with many viral targets ranging from adsorption of the virus to the host cells to release from it, which can result in mechanisms of action complementary to those of existing antiviral drugs.

Examples are virus adsorption inhibitors such as sulphated polysaccharides, saponins and phenolic plant components, virus-cell fusion inhibitors such as mannose- and $N$-acetylglucosamine-specific plant lectins and betulinic acid derivatives, reverse transcriptase inhibitors such as flavones, fla- vans, phloroglucinols and isoquinoline alkaloids, translation inhibitors such as trichosanthin and other single-chain ribosome inactivating plant proteins, maturation inhibitors such as castanospermine, 1-deoxynojirimicin and analogues, and budding (assembly/release) inhibitors such as hypericin and other photosensitisers.

In conclusion, several plant-derived antiviral agents are prime candidates to be pursued for their potential in the systemic therapy and/or prophylaxis of HIV infections. Some of them might be useful as topical agents to inactivate newly formed virus or as adjuvants in combination with other antiviral drugs. It is, however, essential that the plant kingdom as source of new antiviral leads should be explored further and that these investigations should be encouraged and continued.

\section{Acknowledgements}

This review is dedicated to all researchers working in the field of natural products antiviral research. TD is Postdoctoral Researcher and SA is Research Assistant of the Fonds voor Wetenschappelijk Onderzoek - Vlaanderen.

\section{References}

1 Vlietinck, A. J., De Bruyne, T., Vanden Berghe, D. A. (1997) Plant substances as antiviral agents (1997), in: Current Organic Chemistry, Natural Product Chemistry Issue, (Atta-ur-Rahman ed.), Benthem Science Publishers, The Netherlands.

2 De Clercq, E. (1995) Clin. Microbial. Rev. 8, 200-239.

3 Beutler, J. A., Cardellina II, J. H., McMahon, J. B., Boyd, M. R. (1992) J. Nat. Prod. 55, 207-213.

${ }^{4}$ Houghton, P. J., Waldemarian, T. Z., Khan, A. I., Burke, A., Mahmood, N. (1994) Antiviral Res. 25, 235-244.

5 Turano, A., Scura, G., Caruso, A., Bonfanti, C., Luzzati, R., Basetti, D., Manca, N. (1989) AIDS Res. Hum. Retrovir. 5, 183-191.

${ }^{6}$ Basetti, D., Luzatti, R., Di Perri, G., Sepe, G., Furano, A. (1989) J. Infect. 18, 299-301.

7 Boyd, M. R., Hallech, Y. F., Cardellina II, J. H., Manfredi, K. P., Blunt, J. W., McMahon, J. B., Buckheit Jr, R. W., Bringman, S., Schäffer. M., Cragg, G. M., Thomas, D. W., Jato, J. C. (1994) J. Med. Chem. 1740 1745.

${ }^{8}$ McMahon, J. B. M., Currens, M. J., Gulakowski, R. J., Buckheit Jr., R. W., Lachman-Smith, C., Hallock, Y. F., Boyd, M. R. (1995) Antimicrob. Ag. Chemother. 39, 484-488.

${ }^{9}$ Hohenschutz, L. D., Bell, E. A., Jewens, P. J., Leworthy, D. P., Pryce, R. J., Arnold, E., Clardy, J. (1981) Phytochemistry 20, 811 - 814.

10 Nash, R. J., Fellows, I. E., Dring, J. V., Stirton, C. H., Carter, D., Hegarty, M. P., Bell, E. A. (1988) Phytochemistry 27, 1403 - 1404.

11 Scofield, A. M., Fellows, L. E., Nash, R. J., Fleet, G. W. H. (1986) Life Sci. 39, $645-650$.

12 Rupprecht, ?.. M., Mulloney, S., Andersen, J., Bronsen, R. J. (1989) AIDS 2, 149 - 159 .

13 Sunkara, P. S., Bowlin, T. C., Lin, P. S., Sjoersma, A. (1987) Biochem. Biophys. Res. Comm. 148, 206-210.

${ }^{14}$ Walker, B. D., Kowalski, M., Goh, W. C., Kozarsky, K., Krieger, M., Rosen, G., Rohrschneider, L., Haseltine, W. A., Sodroski, J. (1987) Proc. Natl. Acad. Sci. USA 84, 8120-8124.

15 Molyneux, R. J., Pan, Y. T., Tropea, J. E., Benson, M., Kaushal, G. P., Elbein, A. D. (1991) Biochemistry 30, 9981 - 9987.

16 Tropea, J. E., Molyneux, R. J., Kaushal, G. P., Pan, Y. T., Mitchell, M., Elbein, A. D. (1989) Biochemistry 28, 2027-2034.

17 Kite, G. C., Fellows, L. E., Fleet, G. W. J., Liu, P. S., Scofield, A. M., Smith, N. G. (1988) Tetrahedron Lett. 29, 6483-6487.

${ }^{18}$ Montefiori, D. C., Robinson Jr., W. E., Mitchell, W. M. (1988) Proc. Natl. Acad. Sci. USA 85, 9248 -9252. 
${ }^{19}$ Pal, R., Kalyanaraman, V. S., Hoke, G. M., Sarngadharan, M. d. (1989) Intervirology 30, 27-35.

${ }^{20}$ Fishl, M. A., Resnick, L., Coombs, R., Kremer, A. B., Pottage, J. C. Jr., Fass, R. J., Fife, K. H., Powderly, W. G., Collier, A. C., Aspinall, R. L., Smith, S. I., Kowalski, K. G., Wallemark, C. B. (1994) J. Acquired Immun. Defic. Syndr. 7, 139-147.

${ }^{21}$ Tan, G. T., Pezzuto, J. M., Kinghorn, A. D. (1991) J. Nat. Prod. 54, $143-154$.

22 Kakiuchi, N., Hattori, M., Ishii, H., Namba, T. (1987) Planta Med. $22-27$.

23 Sethi, M. L. (1985) J. Pharm. Sci. 74, $889-892$.

24 Tan, T. G., Kinghorn, A. D., Hughes, S. H., Pezutto, J. M. (1991) J. Biol. Chem. 266, 23529-23529.

25 McCormick, J. L., McKee, T. C., Cardellina II, J. R., Boyd, M. R. (1996) J. Nat. Prod. 59, 469-471.

${ }^{26}$ Ngan, F., Chang, R. S., Tabba, H. D., Smith, K. M. (1988) Antiviral Res. 10, 107-116.

27 Tabba, H. D., Chang, R. S., Smith, K. M. (1989) Antiviral Res. 11, $263-274$

${ }^{28}$ Chang, R. S., He, Y. S., Tabba, H. D., Smith, K. M. (1988) Chin. Med. J. 101, $861-865$.

${ }^{29}$ Patel, A. D., Freyer, A. J., Egglerton, D. S., Hultiwonger, R. C., Bean, M. F., Taylor, P. B., Caranfa, M. J., Breen, A. L., Barton, H. M., Johnson, R. K., Herteberg, R. P., Westley, D. W. (1993) J. Med. Chem. 36, $4131-4138$.

${ }^{30}$ Nakashima, H., Ichiyama, K., Hiragama, F., Uchino, K., Ito, M., Saitoh, T., Ueki, M., Yamamoto, N., Ogawara, H. (1996) Antiviral Res. 30. 95-108.

31 McDaniel, H. R., Perkins, S., McAnalley, B. H. (1987) Am. J. Clin. Pathol. 88, 534-538.

32 Balzarini, J., Neyts, J., Schols, D., Hosoya, M., Van Damme, E., Peuman, W., De Clercq, E. (1992) Antiviral Res. 18, 191 - 207.

${ }^{33}$ Müller, W. E., Rennaisen, G. K., Kreuter, M. H., Schröder, H. C., Winkler, L. (1988) J. Acquired Immun. Defic. Syndr. 1, 453-458.

34 Animashaum, T., Mahmood, N., Hay, J., Hughes, R. C. (1993) Antiviral Chem. Chemother, 4, 145-153.

${ }^{35}$ Kashman, Y., Gustafson, K. R., Fuller, R. W., Cardellina II, J. H., McMahon, J. B., Currens, M. J., Buckheit Jr., R. W., Hughes, S. K., Cragg, G. M., Boyd, M. R. (1992) J. Med. Chem. 35, 2735 - 2743.

${ }^{36}$ Patil, M. M., Yanagishita, G., Rodriguez, D. C., Bou-Habib, T., Oravecz, T., Hascall, V. C., Norcrusi, M. A. (1993) AIDS Res. Hum. Retroviruses. 9, 167- 174.

37 Boyer, P. L., Currens, M. J., McMahon, J. B., Boyd, M. R., Hughes, S. H. (1993) J. Virol. 67, 2412 - 2420.

38 Cardellina II, J. H., Bakesh, H. R., McKee, T.C., Boyd, M. R. (1995) Biorg. Med. Chem. Lett. 5, 1011 - 1014.

${ }^{39}$ Chenera, B., West, M. L., Finkelstein, J. A., Dreyn, G. B. (1993) J. Org. Chem. 58, 5605-5606.

${ }^{40}$ Fuller, R. W., Bokesh, H. M., Gustafson, H. R., McKee, T. C., Cardellina II, J. H., McMahon, J. B., Cragg, G. M., Soejarto, D. D., Boyd, M. R. (1994) Biorg. Med. Chem. Lett. 4, 1961 - 1964.

41 Pengsuparp, F., Sirit, M., Hughes, S. H., Soejarto, D. D., Pezutto, J. M. (1996) J. Nat. Prod. 59, 839-849.

42 Hatano, T., Yasuhara, T., Miyamoto, K., Okuda, T. (1988) Chems. Pharm. Bull. 36, 2286-2288.

43 Bourinbalar, A. S., Tan, X., Nagorny, R. (1993) AIDS 7, 129- 130.

44 Tummino, P. J., Ferguson, D., Hupe, L., Hupe, D. (1994) Biochem. Biophys. Res. Comm. 200, 1658 - 1664.

45 Zhao, H., Neamati, N., Hong, H., Mazumder, A., Wang, S., Sunder, S., Milne, G. W. A., Pommier, Y., Burke, T. S. (1997) J. Med. Chem. $40,242-249$.

${ }^{46}$ Mazumder, A., Wang, S., Neamati, N., Nicklaus, M., Sunder, S., Chen, J., Milne, G. W. A., Rice, W. G., Burke, T. R., Pommier, Y. (1996) J. Med. Chem. 39, $2472-2481$.

47 Mahmood, N., Pizza, S., Aquino, K., De Tommasi, N., Piacente, P., Colman, S., Burke, A., Hay, A. J. (1993) Antiviral Res. 22, 189- 199.

${ }^{48}$ Ono, K., Nakane, H., Meng, Z. H., Ose, Y., Sakai, Y., Mizuno, M. (1989) Chem. Pharm. Bull. 37, 1810-1812.
49 Ono, V., Nakane, H., Fuketshima, M., Chermann, J. C., BarréSinoussi, F. (1990) Eur. J. Biochem. 190, 469-476.

50 Kusumoto, I. T., Hattori, M., Miyaichi, Y., Tamimori, T., Hanacha, M., Namba, T. (1991) Shoyakugaku Zasshi 45, 240-254.

51 Spedding, G., Ratty, A., Middleton Jr., H. (1989) Antiviral Res. 12, 99-110.

52 Pengsuparp, F., Lai, L., Constant, H., Fong, H. H. S., Lin, L. Z., Kinghorn, A. D., Pezutto, J. M., Cordell, G. A. (1995) J. Nat. Prod. 58, 1024-1031.

53 Eich, E., Schulz, J., Truman, S., Sarin, J. S., Maidhof, A., Menz, H., Schroeder, H. C., Mueller, W. E. G. (1990) Planta Med. 56, 506507.

${ }^{54}$ Schroeder, H. C., Merz, H., Steffen, R., Mueller, W. E., Sarin, G., Trumm, P. S., Schulz, J., Eich, E. (1990) Z. Naturforsch. 45c, 12151221.

55 Eich, E., Pertz, H., Kaloga, M., Schulte, J., Fesen, M. R., Mazondu, A., Pommier, Y. (1996) J. Med. Chem. 39, 86 - 95.

56 Chen, D.-F., Zhong, S.-X., Chen, K., Zhou, B.-N., Wang, P., Cosentino, L. M., Lee, K.-H. (1996) J. Nat. Prod. 59, 1066- 1068.

57 Sakagami, H., Kawazoe, Y., Komatsu, N., Simpson, A., Ninoyama, M., Konno, K., Yoshida, T., Kuroiwa, Y., Tanama, S. (1991) Anticancer Res. 11, $881-888$.

${ }^{58}$ Lai, P. K., Donovan, J., Takayama, H., Sakagami, K., Tanaka, A., Konno, K., Nonoyama, M. (1990) AIDS Res. Hum. Retrovir. 3, $205-$ 217.

59 Eberhardt, F. L., Young, R. A. (1996) Planta Med. 62, 63-66.

${ }^{60}$ Che, C. T. (1991) in: Economic and Medicinal Plant Research, (Wagner, H., Farnsworth, N. R., eds.), Vol. 5, Chapter 7, p. 167-251.

61 Mahmood, N., Moore, P. S., De Tommassi, N., De Simone, F., Colman, S., Hay, A. J., Pirza, C. (1993) Antivir. Chem. Chemother. 4, $235-240$

62 Nonaka, G. I., Nishioka, I., Nishizawa, M., Yamagishi, T., Kashiwada, Y., Dutschman, G. E., Bodner, A. J., Kikushic, R. E., Cheng, Y. C., Lee, K. H. (1990) J. Nat. Prod. 53, 587-595.

${ }^{63}$ Nishizawa, M., Yamagishi, T., Dutschman, G. E., Parker, W. B., Bodner, A. J., Kilkhuskic, R. E., Cheng, Y. C., Lee, K. H. (1989) J. Nat. Prod. 52, 762-768.

${ }^{64}$ Kashiwada, Y., Nishizawa, M., Yamagishi, F., Tanaka, T., Nonaka, G. I., Contentino, L. M., Smidt, J. V., Lee, K.-H. (1995) J. Nat. Prod. 58, $392-400$.

65 Robinson, W. E. Jr., Cordeiro, M., Abdel-Madek, S., Jia, Q., Chow, S. A., Reinecke, M. G., Mitchell, W. M. (1996) Molecul. Pharmacol. $50,846-855$.

66 Burke, T. R. Jr., Fesen, M. R., Mazumder, A., Wang, J., Caruthers, A. M., Grunberger, D., Driscoll, J., Kohn, F., Pommier, Y. (1995) J. Med. Chem. 38, 4170-4178.

67 Zhao, H., Neamati, N., Mazumder, A., Sunder, S., Pommier, Y., Burke, J. R. Jr. (1997) J. Med. Chem. 40, 1186 - 1194.

68 Neamati, N., Hong, H., Mazumder, A., Wang, S., Sunder, S., Nicklaus, M. C., Milne, G. U. A., Proksa, B., Pommier, Y. (1997) J. Med. Chem. 40, 942 - 951.

69 Gustafson, K. R., Cardellina II, J. H., McMahon, J. B., Pannell, L. K., Cragg, G. M., Boyd, M. R. (1992) J. Org. Chem. 57, 2809-2811.

${ }^{70}$ Lin, T. S., Shinazi, R., Griffith, B., August, E. M., Eriksson, B. F. H., Zhang, D. K., Huang, L., Prusoff, W. H. (1989) Antimicrob. Agents Chemother. 33, 2149-2151.

${ }^{71}$ Lin, T. S., Shinazi, R. F., Zhu, J., Bichi, E., Carbone, R., Sie, Y., Wer, K., Huang, L., Prusoff, W. H. (1993) Biochem. Pharmacol. 46, 251 255.

72 Nakane, H., Arisawa, M., Fujita, A., Koshimura, S., Ono, K. (1991) FEBS Lett. 286, 83-85.

73 Irvin, J. D. (1993) Pharmac. Ther. 21, 371 - 387.

74 McGrath, M. S., Huang, K. M., Caldwell, S. E., Garicn, L., Luk, K. C., Wu, P., Ng, V. C., Crow, S., Danich, J., Manh, J., Deinhart, T., Lekas, P. V., Vennari, J. C., Yeng, H. W., Lipon, J. D. (1989) Prod. Natl. Acad. Sci. USA 86, 2844-2848.

75 Zarling, J. M., Moiran, P. A., Haffar, O., Sins, J., Richman, D. J., Spina, C. A., Myers, D., Keubelbeck, V., Ledbetter, J. A., Uckun, F. M. (1990) Nature 347, $92-95$. 
${ }^{76}$ Girbes, T., Ferreras, J. M., Iglesias, R., Citores, L., De Torre, C., Carbajales, M. L., Jimenez, P., De Beneto, F. M., Munoz, R. (1996) Cell. Molec. Biol. 42, 461 - 471 .

${ }^{77}$ Lee-Huang, S., Kung, H. F., Huang, P. C., Bourinbaiar, A. S., Huang, P. L., Tsai, W. P., Chen, A.-Y., Huang, H. I. (1994) Proc. Natl. Acad. Sci. USA 91, 12208-12202.

${ }^{78}$ Lee-Huang, S., Huang, P. C., Bourinbaiar, A. S., Chen, H. C., Kung, H. F. (1995) Proc. Natl. Acad. Sci. USA 92, 8818-8822.

${ }^{79}$ Kahn, J. O., Gorelich, K. J., Gutti, G., Arci, C. J., Lifson, J. D., Gumbestoglio, J. A., Bostrom, A., Williams, R. (1994) Antimicrob. Agents Chemother. 36, 260-267.

${ }^{80}$ Till, M. A., Zolla-Pazner, S., Gorny, M. K., Patton, J. S., Lehr, J. W., Vitetta, E. S. (1989) Proc. Natl. Acad. Sci. USA 86, 1987-1991.

${ }^{81}$ Pincus, S. H., Wehsly, K., Chesebro, B. (1989) J. Immunol. 142, $3070-3082$.

82 North, J., Neyendorf, H., Levy, J. G. (1993) J. Photochem. Photobiol. B: Biol. 17, 99- 108.

${ }^{83}$ Meruelo, D., Lavie, G., Lavie, D. (1988) Proc. Natl. Acad. USA 85, $5230-5239$.

${ }^{84}$ Lavie, G. F., Valentine, B., Levin, Y., Marur, G., Gallo, G., Lavie, D., Weiner, D., Meruelo, D. (1989) Proc. Natl. Acad. Sci. USA 86, $5963-5967$.

85 Lenard, J., Rabson, A., Vanderoef, R. (1993) Proc. Natl. Acad. Sci. USA 90, 158-162.

${ }^{86}$ Hudson, J. B., Harris, L., Towers, G. H. N. (1993) Antiviral Res. 20 , $173-178$

${ }^{87}$ Fehr, M. J., McCloskey, M. A., Petrick., J. W. (1995) J. Am. Chem. Soc. 117, $1833-1836$.

${ }^{88}$ Chen, S. X., Wan, M., Loh, B.-N. (1990) Planta Med. 62, 381 - 382.

${ }^{89}$ McGuigan, C., O'Connor, T. J., Swords, B., Kinchington, D. (1991) AIDS 5, 1536-1545.

${ }^{90}$ Chu, C. K., Cutler, H. G. (1992) in: Natural Products as Antiviral Agents, Plenum Press, New York.

${ }^{91}$ Hudson, J. B., Harris, L., Teeple, A., Towers, G. H. N. (1993) Antiviral Res. 20, 33-43.

92 Hudson, J. B., Balsa, F., Harris, L., Towers, G. H. N. (1993) Photochem. Photobiol. 57, 675-680.

${ }^{93}$ Konowalchuk, J., Speirs, J. I. (1978) Appl. Environ. Microbiol. 36, 798-806.

${ }^{94}$ Weaver, J. L., Pim, P. S., Dutschman, G., Cheng, Y. C., Lee, K. H., Aszalos, A. (1992) Biochem. Pharm. 43, 2479-2486.

${ }^{95}$ Nakashima, H., Murakami, T., Yamamoto, N., Sakagami, H., Tanuma, S. I., Hatano, T., Yoshida, T., Okuda, T. (1992) Antiviral Res. 18, $91-103$.

${ }^{96}$ Kakiuchi, N., Hattori, M., Namba, T., Nishizawa, M., Yamagishi, T., Okuda, T. (1985) J. Nat. Prod. 48, 614-621.

${ }^{97}$ Okuda, T., Yoshida, T., Hatano, T. (1989) Planta Med. 55, 117-122.

98 Yoshida, T., Ito, H., Hatano, T., Kurata, M., Nakanishi, T., Inada, A., Murata, H., Inatomi, Y., Matsuura, N., Ono, K., Nakane, H., Lang, F. A., Murata, J. (1996) Chem. Pharm. Bull. 44, 1436- 1439.

99 Take, Y., Inouye, Y., Nakamura, S., Allaudeen, R. S., Kubo, A. (1989) J. Antibiotics 42, $107-114$.

100 Nakane, H., Fukushima, M., Ono, K. (1990) J. Nat. Prod. 5, 12341240.

${ }^{101}$ Kakiuchi, N., Kusumoto, I. T., Hattori, M., Namba, T., Hatano, T., Okuda, T. (1991) Phytotherapy Res. 5, 270-272.

${ }^{102}$ Ferrea, C., Canessa, A., Sampietro, F., Cruciani, M., Romussi, G., Basetti, D. (1993) Antiviral Res. 21, 317-325.

${ }^{103}$ Ito, M., Nakashima, H., Baba, M., Sato, A., Pauwels, R., De Clercq, E., Shigeta, S., Yamamoto, N. (1987) Antiviral Res. 7, 127-137.

${ }^{104}$ Hattori, T., Ikumatsu, S., Koivo, A., Matsushita, S., Maeda, Y., Hada, M., Fujimaki, M., Takatsuki, K. (1989) Antiviral Res. 11, 255-261.

${ }^{105}$ Watanabe, H., Mijayi, C., Makino, M., Abo, T. (1996) Biother. 9 , $209-220$.

${ }^{106}$ Ito, M., Sato, A., Hirabayashi, K., Tanabe, F., Shigeta, S., Baba, M., De Clercq, E., Nakashima, H., Yamamoto, N. (1988) Antiviral Res. $10,289-298$.
107 Nakashima, H., Kudo, Y., Kobayashi, N., Motoki, Y., Neushul, M., Yamamoto, N. (1987) Antimicrob. Agents Chemother. 31, 15241528.

108 Nakashima, H., Ohubo, K., Honda, Y., Tamura, T., Matsuda, S., Yamamoto, N. (1989) AIDS 3, 655 - 658.

109 Konoshima, T., Yasuda, I., Kashiwada, Y., Cosentino, C. M., Lee, K. H. (1995) J. Nat. Prod. 58, 1372 - 1377.

110 Xi, H. X., Zong, F. Q., Wan, M., Sim, K. Y. (1996) J. Nat. Prod. 59, $643-645$

111 Kuo, Y.-H., Yang Kuo, L. M. (1997) Phytochemistry 44, 1275 1281.

112 Fujioka, T., Kashiwada, Y., Kilkuskie, R. E., Cosentino, L. M., Ballas, L. M., Jiang, J. B., Janzen, W. P., Chen, I. S., Lee, K.-H. (1994) J. Nat. Prod. 57, 243-247.

113 Mayaux, J. F., Bousseau, R., Pauwels, R., Huet, T., Henin, Y., Dereu, N., Evers, M., Soler, F., Pouyade, C., De Clerq, E., Le Pecq, J. B. (1994) Proc. Natl. Acad. Sci. USA 91, 3564 - 3568.

114 Evers, M., Pouyade, C., Soler, F., Ribeill, Y., Janus, C., Lelievre, Y., Gueguen, J. C., Reisdorf, D., Morize, I., Pauwels, R., De Clercq, E., Henin, Y., Rousseau, A., Mayeux, J. F., Le Pecq, J. B., Derue, N. (1996) J. Med. Chem. 39, 1056-1068.

115 Soler, F., Pouyade, C., Evers, M., Carry, J. C., Hénin, Y., Bousseau, A., Huet, I. T., Pauwels, R., De Clerq, E., Mayaux, J. F., Le Pecq, J. B., Derue, N. (1996) J. Med. Chem. 39, 1069-1083.

116 Sun, H. D., Qiu, S. X., Lin, L. Z., Warg, Z. Y., Lin, Z. W., Pensuparp, T., Pezutto, J. M., Fong, H. R. S., Cordell, G. A., Farnsworth, N. (1996) J. Nat. Prod. 59, 525-527.

117 Boyd, M. R. (1988) in: Aids etiology, diagnosis, treatment and prevention, (De Vita, Helmann, Rosenthal, eds.), Lippincott, Philadelphia, $305-319$.

\section{Prof. A. J. Vlietinck}

Department of Pharmaceutical Sciences

University of Antwerp (UA)

Universiteitsplein 1

B-2610 Antwerp

Belgium

E-mail: vlietink@uta.ua.ac.be

Fax: +32-3-8202709 